\title{
Natuurlijke, super-natuurlijke en design slagaderen
}

\author{
Citation for published version (APA):
}

Post, M. J. (2005). Natuurlijke, super-natuurlijke en design slagaderen. Maastricht University. https://doi.org/10.26481/spe.20050304mp

Document status and date:

Published: 04/03/2005

DOI:

10.26481/spe.20050304mp

Document Version:

Publisher's PDF, also known as Version of record

\section{Please check the document version of this publication:}

- A submitted manuscript is the version of the article upon submission and before peer-review. There can be important differences between the submitted version and the official published version of record.

People interested in the research are advised to contact the author for the final version of the publication, or visit the DOI to the publisher's website.

- The final author version and the galley proof are versions of the publication after peer review.

- The final published version features the final layout of the paper including the volume, issue and page numbers.

Link to publication

\footnotetext{
General rights rights.

- You may freely distribute the URL identifying the publication in the public portal. please follow below link for the End User Agreement:

www.umlib.nl/taverne-license

Take down policy

If you believe that this document breaches copyright please contact us at:

repository@maastrichtuniversity.nl

providing details and we will investigate your claim.
}

Copyright and moral rights for the publications made accessible in the public portal are retained by the authors and/or other copyright owners and it is a condition of accessing publications that users recognise and abide by the legal requirements associated with these

- Users may download and print one copy of any publication from the public portal for the purpose of private study or research.

- You may not further distribute the material or use it for any profit-making activity or commercial gain

If the publication is distributed under the terms of Article $25 \mathrm{fa}$ of the Dutch Copyright Act, indicated by the "Taverne" license above, 
062 
Natuurlijke, super-natuurlijke en design slagaderen 
Colofon

Basisontwerp en realisatie: Unigraphic, Universiteit Maastricht.

ISBN 90-5681-228-9

NUR 874

Alle rechten voorbehouden. Niets uit deze uitgave mag worden verveelvoudigd, opgeslagen in een geautomatiseerd gegevensbestand of openbaar gemaakt, zonder voorofgaande schriftelijke toestemming van de auteur of uitgever. 


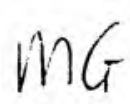

$\checkmark A C$

\section{Natuurlijke, super-natuurlijke en design slagaderen}

Rede

uitgesproken bij de aanvaarding van het ambt van hoogleraar Vascular Physiology and Tissue Engineering aan de Universiteit Maastricht en hoogleraar Angiogenesis in tissue Engineering aan de Technische Universiteit Eindhoven

op vrijdag 4 maart 2005

door

Mark Post

U

MU Universiteit Maastricht 
PPN. ifg get o5i

Universitertaliblintheek

Universitteit Maastricht 
Geachte rectoren, leden van de faculteiten Geneeskunde van Maastricht en Biomedische Technologie van Eindhoven, collega's, familie, vrienden en andere genodigden,

U heeft allen ongetwijfeld gelezen dat deze leerstoel een nogal ingewikkelde en specifieke formulering heeft, waarin de woorden angiogenese (angiogenesis in Engels) en tissue engineering (geen Nederlands woord voor) voorkomen. Ik zal duidelijk maken waarom deze combinatie een logische is en waar deze leerstoel uit voortgekomen is. Ik zal vervolgens de aandachtsgebieden van beide onderwerpen toelichten en mijn huidige en toekomstige inspanning schetsen. Tenslotte wil ik van deze gelegenheid gebruik maken de betekenis van "oude" -ik gebruik dit woord met opzet om te polariseren- disciplines zoals Fysiologie voor onderzoek en onderwijs te onderstrepen.

\section{Inleiding}

angiogenese

Het aandachtsgebied angiogenese, dwz vorming van nieuwe bloedvaten, is nieuw en gestart vanuit de notie -en vroege observaties- dat weefsels nieuwe bloedvaten nodig hebben om te kunnen groeien (fig 1). Voor groei en overleving zijn immers zuurstof en grondstoffen noodzakelijk die alleen via het bloed voldoende snel en efficiënt worden aangevoerd. Deze afhankelijkheid van bloedvoorziening geldt voor gezonde weefsels maar bijvoorbeeld ook voor kankergezwellen.

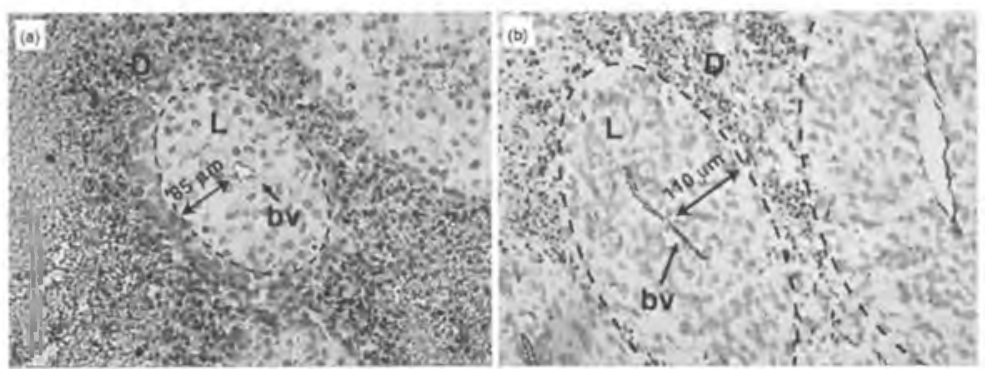

Figuur 1. Tumorcellen van een melanoom (a) of prostaat kanker (b) zijn afhankelijk van bloedvaten. Rondom de bloedvaten (bv) zijn de cellen in leven, terwijl ze op zekere kritische afstand van de bloedvaten doodgaan (D). De kritische afstand is specifieke voor elk type cel. Reproductie van I. Folkman ${ }^{2}$ 
Beide weefsels reageren op zuurstof tekort door produktie en uitscheiding van groeifactoren die leiden tot de nieuwvorming van vaten Een van de grondleggers van de angiogenese is dr Folkman geweest die in een vroeg stadium ( \pm 35 jaar geleden) ingezien heeft dat remming van angiogenese de groei van kankergezwellen zou kunnen remmen. inmiddels zijn er vele experimentele en klinische studies gaande of voltooid die wijzen in de richting van uiteindelijk succes van behandeling van kankergezwellen door neutraliseren van de vaatgroei. Hoewel zeer recent het eerste middel goedgekeurd is dat door het remmen van vaatgroei de groei van dikke darm kankergezwellen remt, zal het nog wel even duren voordat patienten routinematig met dit soort middelen worden behandeld. Enkele jaren na de notie om tumor angiogenese te remmen -cardiologen lopen meestal wat achter op oncologen, immunologen en hematologen- is de gedachte gerezen dat hart- of skeletspier weefsel dat onvoldoende wordt doorbloed door bijvoorbeeld een afgesloten kransslagader, baat zou kunnen hebben bij stimulering van angiogenese.

Hiermee is het gebied van de zogenaamde therapeutische angiogenese ontstaan, waarin men beoogt om met behulp van groeifactoren nieuwe vaten te laten groeien die niet of nog niet van nature zijn ontstaan: "super-natuurlijke" slagaderen dus. Dit gebied is inmiddels ver ontwikkeld maar patiënten worden vooralsnog alleen in het kader van klinische trials behandeld.

\section{Tissue engineering}

Tegelijkertijd (mid jaren 70 ) is tissue engineering opgekomen, met als grondgedachte dat organen of weefsels vervangen kunnen worden door kunstweefsels die bestaan uit meer of minder gespecialiseerde cellen en een ondersteunende structuur die vorm en stevigheid verleent3. Samen zouden deze de functie van de te repareren organen zoveel mogelijk kunnen overnemen. Deze kunstweefsels worden buiten het lichaam gekweekt totdat ze groot genoeg zijn voor implantatie. Hier doet zich hetzelfde probleem voor als bij tumoren: bij een zekere omvang die afhankelijk is van de metabole activiteit van de cellen, is een netwerk van bloedvaten nodig

Deze voorwaarde maakt het design van weefselimplantaten erg ingewikkeld, temeer omdat een vaatnetwerk dikwijls niet de enige wens is. Zenuwvoorziening of de aanleg van gespecialiseerde weefselstructuren zoals elektrisch geleidende cel-cel verbindingen in het hart, galkanalen in de lever of filtreereenheden in de nier, lijken allen bijna 
onmogelijke taken voor weefselontwerpers. Het is niet voor niets dat de eerste successen geboekt zijn met een verhoudingsgewijs eenvoudig weefsel zoals bot. Niet alleen is bloedvatvorming van belang voor de overleving van cellen in het inwendige van grotere weefselimplantaten, er is ook behoefte aan kunstmatige vaten en hartkleppen voor gebruik in de cardiovasculaire chirurgie. Dit is waar de afdeling Biomedische Technologie in Eindhoven zich vooral mee bezighoudt. Wanneer men de ongeëvenaarde illustratie van Netter nauwkeurig bekijkt (fig 2), zal duidelijk zijn dat het ontwerpen en fabriceren van nieuwe vaten -'design slagaderen'- geen sinecure is.
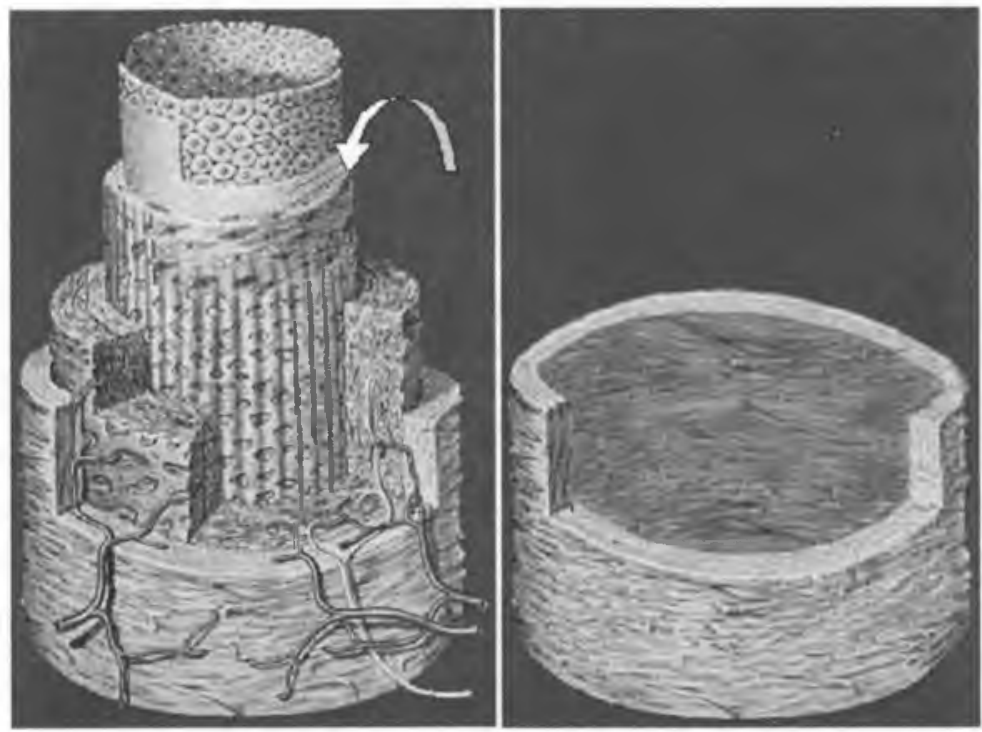

Figuur 2. Schematische doorsnede van een slagader (arterie). Adaptie van FNetter. De witte pijl wijst op de aanvankelijk dunne laag waar vet ophoopt bij aderverkalking. Het rechter panel toont een 'design slagader', zoals die er op dit moment uitziet.

Deze slagader is uit vele lagen opgebouwd die elk hun specifieke functie (en dysfunctie) hebben. De witte pijl wijst op een zeer dunne laag waar de meest voorkomende afwijking van slagaderen, aderverkalking, start.

Met een knipoog naar mijn collega's van tissue engineering laat ik hierbij ook zien waar we op dit moment zijn met onze 'design' arteriën. 
Ze doen in eenvoud en strakheid niet onder voor design meubelen. Dit streven naar eenvoud kan overigens goede redenen hebben. De eenvoud en snelheid waarmee een implantaat gemaakt kan worden bepaalt voor een groot deel het praktische succes. Indien men patiënt-eigen cellen gebruikt, wil men in de meeste gevallen weinig tijd verliezen tussen het afnemen van cellen en het implanteren van een kunstweefsel. Uiteraard gebruiken we bij voorkeur patiënt-eigen cellen om afweer problemen te voorkomen. Het probleem is dat we niet van te voren kunnen voorspellen of eenvoudige weefsels beter of slechter functioneren, omdat eenmaal geimplanteerd het weefsel in belangrijke mate verandert onder invloed van de nieuwe gastheer. Het is dus goed verdedigbaar om eerst in bijvoorbeeld proefdieren te testen of eenvoudige ontwerpen voldoen. Ik heb de indruk dat deze vroege testfase bij meubelen weleens wordt overgeslagen.

\section{Drie mechanismen van neovascularisatie}

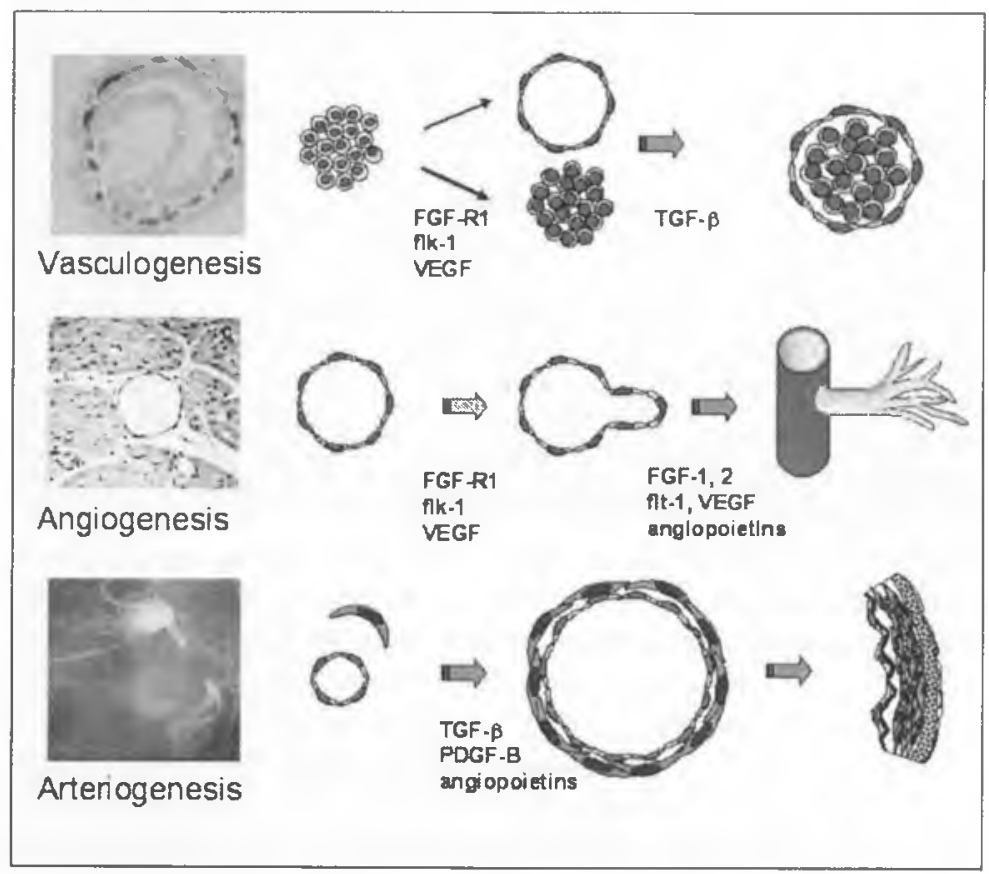

Figuur 3. Drie typen van neovascularisatie: Vasculogenese, angiogenese en arteriogenese. 
Onze bloedvaten vormen samen het grootste orgaan in ons lichaam en de centrale plaats die het inneemt maakt het enerzijds kwetsbaar voor ziekteprocessen, terwijl anderzijds aandoeningen van bloedvaten verstrekkende consequenties kunnen hebben voor belangrijke organen als het hart en de hersenen. Wanneer de bloedvoorziening bijvoorbeeld naar het hart onvoldoende is, ontstaat angina pectoris of zelfs een hartinfarct. Gelukkig kan ons lichaam, en dat van vele diersoorten, spontaan zorgen voor de vorming van nieuwe bloedvaten, een proces dat neovascularisatie wordt genoemd en onder andere door angiogenese plaatsvindt. ledereen heeft dit allemaal verschillende keren, hopelijk onbewust, meegemaakt: de rode kleur in het centrum van een vers litteken is het resultaat van neovascularisatie in de wondranden. Ongeveer een kwart van de wereldbevolking wordt maandelijks aan neovascularisatie in de eierstokken en het baarmoeder-slijmulies herinnerd.

voordat ik overga tot de verschillende typen neovascularisatie en in weerwil van de illustratie van Netter (fig 2), moet ik hier ingaan op 'mijn' definitie van een bloedvat. Een bloedvat is een door endotheelcellen begrensde cylinder, waar bloed door heen stroomt. Deze cylinder krijgt, afhankelijk van de bloeddruk, diameter en specifieke functie, meer of minder bekledende cellen en andere structuren eromheen. Er worden 3 processen of mechanismen onderscheiden waardoor bloedvaten kunnen groeien: vasculogenese, angiogenese en arteriogenese'.

Vasculogenese is het ontstaan van vasculaire netwerken uit groepjes stamcellen. Dit proces is verantwoordelijk voor de initiatie van het bloedvat stelsel tijdens de vroege embryonale ontwikkeling, zelfs al voordat er sprake is van een bloedsomloop. Recent is duidelijk geworden dat stamcellen of precursor cellen ook deelnemen aan vaatgroei in volwassenen, zij het dat de kwantitatieve bijdrage nog onbekend is. Als er eenmaal een vaatbed is kunnen er nieuwe vertakkingen ontstaan, als takken aan een boom. Dit proces wordt angiogenese genoemd. Aldus gevormde kleine vaten kunnen onder invloed van groeifactoren of hemodynamische stimuli zoals bloedstroom, indrukwekkend uitdijen tot slagaderen van een volwassen caliber terwijl de wand van het bloedvat steeds dikker wordt en structuren krijgt. Dit proces -arteriogenese genoemd-is ook verantwoordelijk voor de snelle groei van collateraal arterièn. Collateraal arteriën zijn sluiproutes die het bloed neemt wanneer de hoofdweg geblokkeerd is, bijvoorbeeld door aderverkalking. Deze kan men vergelijken met een carpool/wissel strook naast drukke verkeers-aders, alleen helpen collateraal arteriën dikwijls wel om de file op te lossen. De snelheid en efficientie waarmee we deze collateraal 
arteriën kunnen laten groeien bepalen in sterke mate hoe ernstig onze klachten zijn wanneer we een belangrijke vernauwing in een slagader, bijvoorbeeld een kransslagader in het hart, hebben.

Voor deze nieuwvorming van bloedvaten beschikken we over een aantal zeer krachtige hormonen, zoals FGF-2, VEGF en PDGF, die ook wel groeifactoren genoemd worden. Slechts om aan te geven hoe ingewikkeld dit gebied is geworden vermeld ik hier dat er op dit moment 23 soorten FGF, 5 soorten VEGF en 5 soorten PDCF zijn.

Daar komen nog een aantal zogenaamde splice variants bij. Dit zijn verkorte versies van groeifactoren die soms andere functies hebben dan de oorspronkelijke familieleden. Voor deze groeifactoren bestaan receptoren, 4 voor FGF, 3 voor VECF en 2 voor PDGF die ervoor zorgen dat deze factoren een effect in de cel teweeg brengen. Al deze groeifactoren zijn op directe of indirecte manier in staat om de vorming van bloedvaten te starten.

Het bijzondere is dat in het laboratorium maar drie ingrediënten nodig zijn om bloedvat-achtige structuren te laten groeien: endotheelcellen, een groeifactor en een eiwit waarop de endotheelcellen kunnen hechten. Het eiwit en de groeifactor zijn zelfs niet eens geweldig specifiek, vele geteste eiwitten en groeifactoren hebben deze eigenschap. Dit geeft aan dat een bloedvat een van de gemakkelijkste structuren is om te kweken.

\section{Therapeutische neovascularisatie}

Wetenschappers die neovascularisatie bestuderen doen dit meestal in het kader van tumoren of bij aandoeningen die het gevolg zijn van zuurstoftekort, zoals het hartinfarct. De nadruk bij tumoren ligt natuurlijk op het remmen van neovascularisatie terwijl we in onze groep pogen om neovascularisatie te stimuleren, de zogenaamde therapeutische neovascularisatie. Het aanvankelijke, wellicht wat naieve, idee dat toediening van extra groeifactor zou leiden tot verhoogde neovascularisatie blijkt in de praktijk maar matig te werken. In een laboratorium setting onder streng gecontroleerde omstandigheden leidt extra groeifactor wel tot nieuwvorming van vaten, maar tijdens de eerste klinische testen in grotere groepen patiënten was het resultaat tot nog toe teleurstellend. Dit kan twee redenen hebben. Of het idee deugt niet, of de praktische uitwerking is nog niet goed genoeg.

Het kan inderdaad zijn dat de hypothese niet correct is. Sommige groeifactoren, zoals VEGF, worden al in hoge mate aangemaakt onder invloed van zuurstoftekort. Het mechanisme, dat verloopt via hypoxia inducible factor 1 alfa (HIF-1 $\alpha$ ), is zeer goed beschreven en lijkt uitermate efficient (fig 4). Het blijkt echter dat de normale verhoging van (HIF- 
$1 \alpha$ ), bij zuurstoftekort lager is bij ouderdom en diabetes, wat in beide gevallen gepaard gaat met verminderde VEGF productie en gestoorde angiogenese (voor review zie Cao et al4).

Hypoxie leidt ook tot uitscheiding van FGF-1, FGF-2 en tot een toename van het aantal bindingplaatsen voor FGFs in de celmembraan van endotheelcellen. Als intracellulaire eiwitten zijn FGF-1 en FGF-2 al in hoge mate aanwezig in normale weefsels, dus verhoogde aanmaak lijkt niet nodig te zijn. Ook voor andere groeifactoren zoals PDGF en HGF is het onvoldoende duidelijk dat suppletie effect zou hebben. Wel komen er steeds meer aanwijzingen dat ziekte, genetische achtergrond of ouderdom leiden tot een verminderde response van groeifactoren. Zo is een verminderde neovascularisatie in harten van oude dieren terug te voeren tot een lage PDGF-AB productie. Verschillende laboratoria hebben aangetoond dat de VEGF secretie eveneens is verminderd in oudere dieren en er zijn aanwijzingen dat hetzelfde geldt voor mensen (zie4).

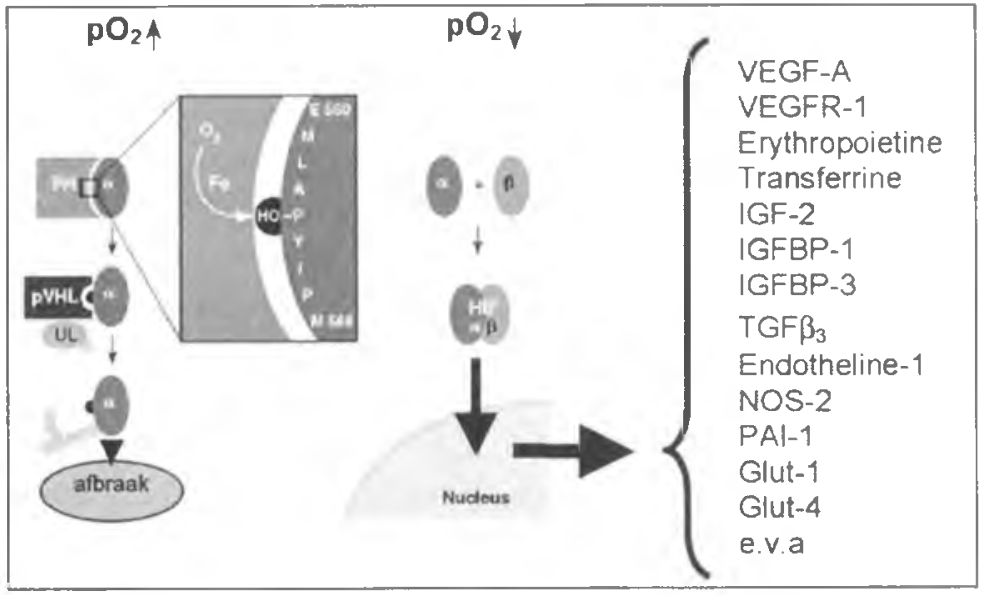

Figuur 4. HIF-1a is het best beschreven zuurstof afhankelijke mechanisme van groeifactor regulatie. Bij normale zuur-stofspanning, wordt HIF-ia afgebroken na hydroxylering van prolines in HIF. Bij lage zuurstof-spanning wordt de afbraak geremd en kan HIF-1a als transcriptie factor fungeren voor O.a. VEGF-A en de VEFGR-1 receptor. Naar Zhu et al.5

Er zijn dus redenen om aan te nemen dat de productie van groeifactoren kan achterlopen op de vraag en dat extra toediening van groeifactoren zinnig zou kunnen zijn, hoewel voor elke groeifactor en ziekte dit opnieuw gevalideerd moet worden. 
De tweede mogelijkheid is dat de praktische uitwerking nog niet goed genoeg is. In zekere zin zijn we op het verkeerde been gezet doordat tamelijke eenvoudige toedieningsvormen van bijvoorbeeld FGF-2 en VECF effectief bleken in een groot aantal experimentele studies afkomstig van verschillende laboratoria, waaronder ons eigen laboratorium. Het is niet de eerste keer dat we uitstekend in staat zijn om een kunstmatig opgewekte ziekte bij muizen of varkens te genezen, terwijl we falen bij de mens. Dit is te verklaren doordat de testsituatie in de kliniek veel meer variabelen kent, zoals leeftijd, onderliggende ziekte, geneesmiddelen gebruik en wisselende ernst van de doorbloedingsstoornis. Hierdoor wordt de test ongevoeliger ${ }^{6}$. In het specifieke geval van hart- en vaataandoeningen als gevolg van een doorbloedingsstoornis is het interessant dat alle patienten in deze klinische trials aanzienlijk verbeterden, ook degene die een inactief 'geneesmiddel', ook wel placebo genoemd, kregen 7 Als dit al iets aantoont, is het dat met goede conventionele medische begeleiding een belangrijke winst te boeken is in de kwaliteit van het leven van patienten met vaatlijden in de benen of het hart. Zeker tijdens een zeer technisch onderzoek zoals het onze, is het goed dat men zich blijft realiseren dat medisch technische noviteiten slechts een aanvulling zijn op goede medische begeleiding, bestaande uit leefregels, controle op uitvoeren van leefregels, regelmatige aandacht, controle van geneesmiddelen gebruik en vele andere schijnbare details.

Inmiddels is meer bekend over de effectieve toediening van groeifactoren. Twee recente studies hebben duidelijk gemaakt dat de wijze van toediening, de dosering en de duur van de therapie uitermate belangrijk zijn voor het eind resultaat. Dit zal voor farmaocologen en farmacotherapeuten geen verrassing zijn. Des te verbazingwekkender is het dat hier weinig systematisch onderzoek naar is gedaan.

De eerste studies op dit gebied van Keshet's groep toonden aan dat kortdurende blootstelling aan verhoogde spiegels van VEGF leidt tot de vorming van een onregelmatig vaatbed dat ernstig dysfunctioneel is en weer desintegreert zodra de groeifactor ontnomen wordt ${ }^{8}$. Wanneer de expositie aan VEGF wordt verlengd tot 4 weken of meer, stabiliseren de vaten zich, krijgen een mooie opbouw en blijven bestaan, zelfs wanneer VEGF niet meer aanwezig is. Hetzelfde hebben we in ons eigen laboratorium bereikt met een combinatie van andere groeifactoren 9 .

De studie van Keshet is een prachtig voorbeeld van een simpele en ogenschijnlijk zeer fundamentele wetenschappelijke proef waarvan de resultaten vergaande consequenties hebben voor uiteindelijke thera- 
peutische toepassing van groeifactoren. In een ze studie van de groep van Blau, werd op elegante wijze aangetoond dat de hoeveelheid VEGF in het micromilieu bepaalt of extra vaatgroei normaal, functioneel en blijvend of juist abnormaal, dysfunctioneel en tijdelijk is ${ }^{10}$. Zij maakten gebruik van gladde spiercellen die genetisch gemodificeerd waren zodat ze overmatig VEGF aanmaakten. Met deze techniek is er niet veel controle over de hoeveelheid VEGF die gemaakt wordt. Sommige cellen maken veel VEGF, anderen weinig. Omdat bij de gebruikte techniek het gen in het DNA van de cel is geincorporeerd, maken alle dochtercellen evenveel VEGF als de moedercel. Men krijgt dus families (klonen) waarin alle cellen veel of juist weinig VEGF produceren. In deze studie werden implantaten met cellen die weinig VEGF maken vergeleken met bovenmatige VEGF producenten, terwijl de totale hoeveelheid VEGF gelijk gehouden werd door aanpassing van de hoeveelheid cellen die ingebracht werden. Ondanks de gelijke totale hoeveelheid VECF, waren de vaten bij de implantaten met lage VEGF productie veel beter dan bij de hoge producenten. Uit deze twee studies blijkt dat de toedieningsvorm van VEGF zeer kritisch is. Dit geldt waarschijnlijk ook voor andere groeifactoren.

Uit de klinische studies is gebleken dat groeifactor toediening veilig is. Toch zijn er belangrijke potentiële bijwerkingen die direct gerelateerd

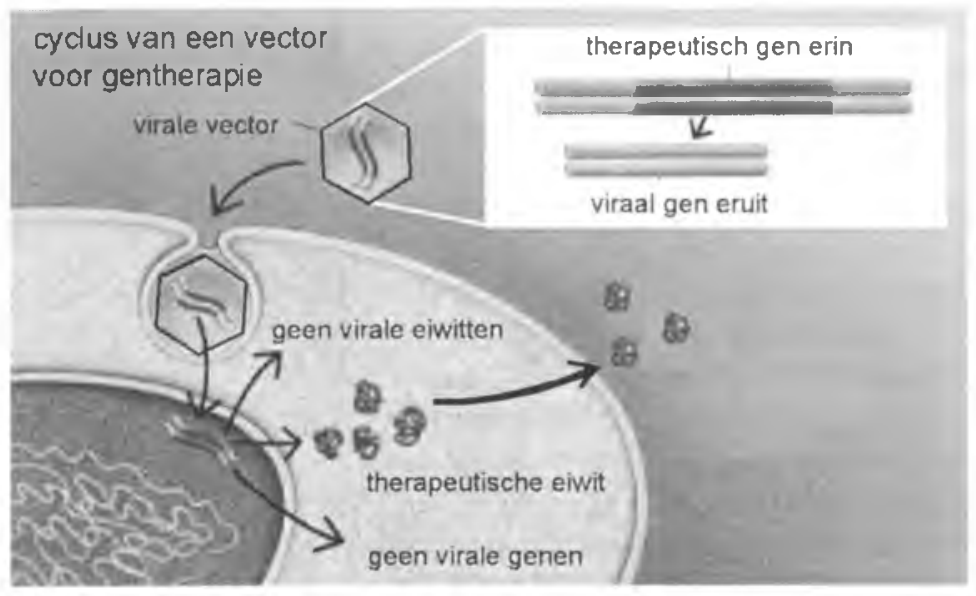

Figuur 5. Principe van gen therapie. Een virale vector met een therapeutisch gen brengt het gen in de acceptor cel waar het afgelezen wordt en tot productie van het therapeutische eiwit leidt. Figuur naar Friedmann $n^{12}$ 
zijn aan hun gewenste effect, zoals toename van tumor groei, verergering van vaatgroei in het netvlies van diabetici en mogelijk zelfs verergering van aderverkalking". Om die reden heeft iedereen zich tot nog toe toegelegd op lokale toediening van deze groeifactoren.

Gegeven dat we een langzame en langdurige afgifte van een groeifactor nodig hebben, wordt er op twee fronten onderzoek gedaan. Er worden gelen ontwikkeld die de eiwitten langzaam afgeven en gemakkelijk toe te dienen zijn met bijvoorbeeld een injectienaald. Het ontwerpen van een gel die inert, d.w.z. geen ontstekingsreactie van het lichaam oproept, en gemakkelijk toedienbaar is en een gunstig profiel heeft voor wat betreft afgifte van eiwitten, blijkt een weerbarstig probleem te zijn. Het recente succes met gecoate stents die geleidelijk een medicament afgeven, doet vermoeden dat oplossing van dit probleem slechts een kwestie van tijd is. De tweede oplossing van langzame en langdurige afgifte van groeifactoren wordt gezocht in gen therapie. Hierbij wordt een onschuldig gemaakt virus gebruikt om een gen dat codeert voor een groeifactor in lichaamscellen te introduceren (fig 5). De lichaamscellen, bijvoorbeeld de hartspiercellen, gaan als fabriek van de groeifactor fungeren, op vergelijkbare wijze zoals tegenwoordig in de farmaceutische industrie humaan insuline door gistcellen wordt gemaakt. Er kleven vele bezwaren aan gen therapie en de technische uitdagingen om deze te overwinnen zijn zeker niet kleiner dan bij de eerst genoemde methode. Het meest fundamentele en wellicht het minst gemakkelijk op te lossen probleem is dat er onvoldoende controle is over de plaats, mate en duur van groeifactor productie.

Dit gedeelte van ons onderzoek is toegepast en leidt hopelijk binnen niet al te lange termijn tot super-natuurlijke arteriën.

\section{Arteriogenese of collateraal vorming: mechanisme en beeldvorming}

Ik heb eerder gesuggereerd dat er verschillen zijn in de mate en snelheid waarmee individuen collateralen kunnen recruteren. Uitgaande van de mijns inziens waarschijnlijke hypothese dat deze collateralen ontstaan uit vooraf bestaande, maar kleine, vaatverbindingen is het mogelijk dat deze verschillen berusten op anatomische verschillen in vaatpatroon: als men geen vaatverbindingen heeft kan men ze ook niet omvormen tot functionele collateralen (fig 6 , hypothese 1 ). 


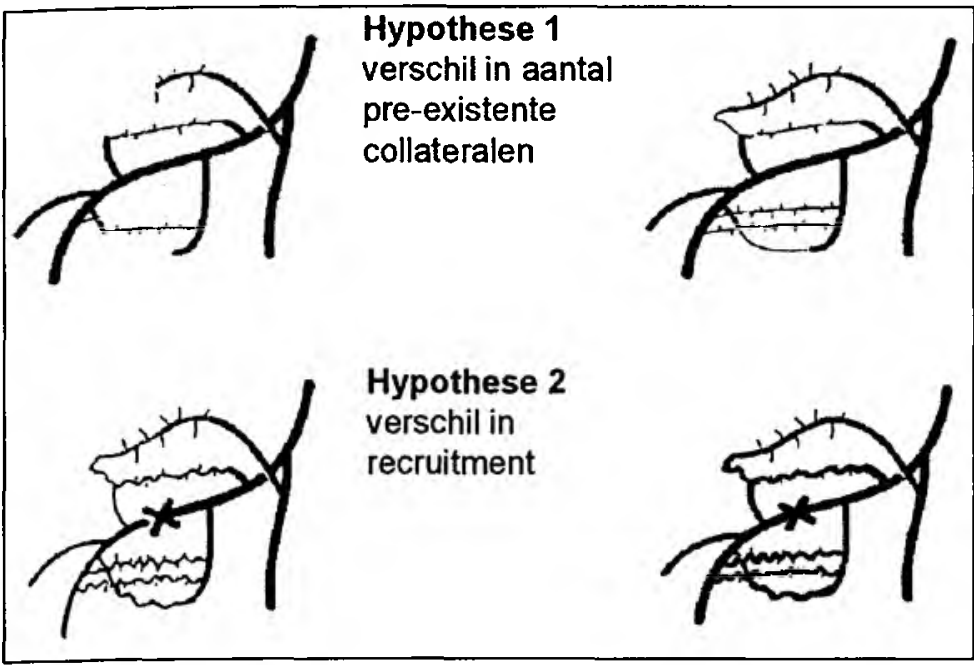

Figuur 6. Twee hypothesen die verschillen in collateralisatie tussen individuen kan verklaren (adaptatie van Helisch et al13).

Anderzijds is het denkbaar dat de verbindingen er wel zijn, maar dat men ze niet kan recruteren door bijvoorbeeld een stoornis in de functie van het endotheel, zoals bij diabetes is geconstateerd (fig 6, hypothese 2). Beide mogelijkheden zijn wetenschappelijk zeer interessant, ofschoon bestudering van het laatste mechanisme, en de defecten hierin, eerder zal leiden tot therapeutische interventie. De groei van collateralen door afsluiten van een grote arterie, kan nauwkeurig over de tijd worden vervolgd. Het is een complex proces waarbij alle lagen van de arteriewand betrokken zijn. Ondanks dat kan in een paar weken tijd de diameter van de arterie tot 20 keer zo groot worden, bijvoorbeeld van $0.1 \mathrm{~mm}$ tot $2 \mathrm{~mm}$. Dit lijkt nog steeds klein, maar de bloedstroom door een dergelijke arterie stijgt hiermee theoretisch met een factor 160.000 . Op dit moment zijn we bezig met een grootschalige inventarisatie van genen die gedurende dit proces meer of minder geactiveerd worden. Door de moderne micro-array techniek zijn we in staat om tegelijkertijd naar 12.000 genen te kijken. Vervolgens wordt het belangrijk om uit het aantal genen dat verandert -voor de meeste biologische processen is dat rond de 30o- die genen te selecteren die interessant lijken. Deze worden nauwkeuriger onderzocht, waarbij vragen beantwoord worden zoals "in welke cel wordt dit gen geactiveerd?" en "wat is de functie van deze genactivatie?". Het doel van deze operatie is om het proces 
van arteriogenese beter te begrijpen en om aanknopingspunten te vinden voor stimulatie van arteriogenese in patiënten die kampen met zuurstoftekort in benen of hart. Daarnaast leidt gedetailleerde kennis van arteriogenese en angiogenese hopelijk tot nieuwe diagnostische methoden om in een vroeg stadium neovascularisatie te herkennen. De overheid heeft gelukkig een belangrijk initiatief van de Universiteit Maastricht, de Technische Universiteit Eindhoven, Philips en Organon gesteund om nieuwe diagnostische methoden te ontwikkelen op het gebied van hart- en vaatziekten.

Het initiatief richt zich op zogenaamd "molecular imaging", dat wil zeggen dat contrastmiddelen worden ontwikkeld, voor MRI, PET, nucleaire scan of echografie, die aan specifieke moleculen binden die kenmerkend zijn voor een bepaald biologisch proces, bijvoorbeeld neovascularisatie. Ook belangrijke aandoeningen als aderverkalking en hartfalen worden bestudeerd. Aangezien de groeiende vaten in het begin nog zeer klein zijn, kunnen ze met gangbare contrastmiddelen en beeldvormende technieken niet in beeld worden gebracht. Echter als contrast bindt aan een molecuul (target) dat de aanwezigheid van beginnende neovascularisatie verraadt, en daardoor ophoopt, worden deze kleine vaten als het ware wel zichtbaar. Dit is een voor academische begrippen groot consortium van samenwerkende groepen in Maastricht en Eindhoven wat extra mogelijkheden schept om in relatief korte tijd een theoretisch concept uit te werken tot een bruikbare diagnostische methode. De uitdaging van onze groep in molecular imaging is drievoudig. Ten eerste is het spannend om nieuwe targets op het endotheel te zoeken die kenmerkend zijn voor neovascularisatie. Dit opent immers nieuwe vroeg-diagnostische perspectieven om bijvoorbeeld het succes van pro- of anti-neovascularisatie therapie te meten. De tweede uitdaging is om op moleculair, subcellulair of cellulair niveau aan te tonen dat het contrastmiddel ook daar bindt waar het theoretisch verwacht mag worden. Vele stoffen die targets kunnen binden zullen immers ook een non-specifieke binding vertonen die de signaal-ruis verhouding ernstig kan verstoren. Tenslotte mogen we aannemen dat het gebruik van deze nieuwe gereedschappen ons wat leert over de biologie van neovascularisatie. Gezien de verschillende onderliggende mechanismen en verschijningsvormen van angiogenese en arteriogenese, lijkt het voor de hand te liggen dat we deze selectief maar tegelijkertijd kunnen afbeelden met behulp van moleculaire imaging methodieken.

Als dat inderdaad het geval is kunnen we voor de eerste keer de anatomische en mogelijk ook functionele relatie tussen collateralen en 
angiogenetische vaatbedden bestuderen, door gebruik te maken van verschillende markers of targets. Het is namelijk waarschijnlijk dat deze vormen van neovascularisatie meestal tegelijk optreden. Dit is enerzijds af te leiden uit de vele observaties dat groeifactoren zowel angiogenese als arteriogenese stimuleren en anderzijds uit een aantal studies waarin beiden tegelijkertijd en naast elkaar optreden. Met name de techniek die door prof Spaan uit het AMC is ontwikkeld stelt ons in staat om zelfs in ingewikkelde vaatbedden als het kransslagader systeem van het hart de collateralen afzonderlijk van de angiogenetische vaatbedden te visualiseren mits we over selectieve contrast middelen voor beide processen beschikken.

\section{Tissue engineering}

Wat is nu de plaats van 'design arteriën'? Wanneer een grote slagader is afgesloten, meestal door vergaande aderverkalking, wordt gekozen voor een chirurgische ingreep, zoals het leggen van een 'omleiding'. Dit kan een ader zijn of een kunststof vat. Dit geeft bevredigende resultaten mits de omleidingen wijd genoeg zijn en er bloed er met voldoende snelheid doorheen kan stromen. In kleinere arteriën, bijvoorbeeld met een diameter kleiner dan $2 \mathrm{~mm}$, werkt dit niet goed en raken de aderen of kunstvaten snel verstopt. Levende arteriën, zoals de beoogde producten van tissue engineering, zijn wellicht beter als we ze zodanig maken dat de eigenschappen zoveel mogelijk lijken op die van de natuurlijke vaten. Ik heb eerder gesuggereerd dat dit een hele uitdaging is. Het maken van weefsel berust in de meeste gevallen op het ontwerpen van een drager substantie en het kweken van cellen in en op deze drager. Dit kweken gebeurt in bioreactoren waarin optimale kweekomstandigheden worden gecreëerd en waarin het mogelijk is om het weefsel mechanisch te conditioneren. De drager is veelal een afbreekbaar polymeer dat structuur en stevigheid biedt aan de cellen en dat in elke gewenste vorm kan worden gemaakt. Cellen, bij voorkeur dus lichaamseigen cellen, worden in de drager 'gezaaid'. Vervolgens wordt het weefsel gekweekt. Dit is nodig om de cellen te laten acclimatiseren, een hogere celdichtheid te krijgen door celdeling en om de cellen te stimuleren om gedifferentieerde functies te gaan vervullen. Het is vrijwel onmogelijk om meteen voldoende cellen te zaaien: om bijvoorbeeld een bloedvat van $5 \mathrm{~cm}$ met een diameter van $1.5 \mathrm{~mm}$ en een dikte van $0.1 \mathrm{~mm}$ te bevolken zijn ongeveer 100 miljoen cellen nodig. De cel heeft dus twee opdrachten die niet goed met elkaar te verenigen zijn: deling en specialisatie, ook wel differentiatie genoemd. Celsoorten die snel delen zijn vaak onge- 
differentieerd en sterk gedifferentieerde cellen zoals hartspiercellen of zenuwcellen delen niet of nauwelijks. Zogenaamde stamcellen kunnen dit echter wel.

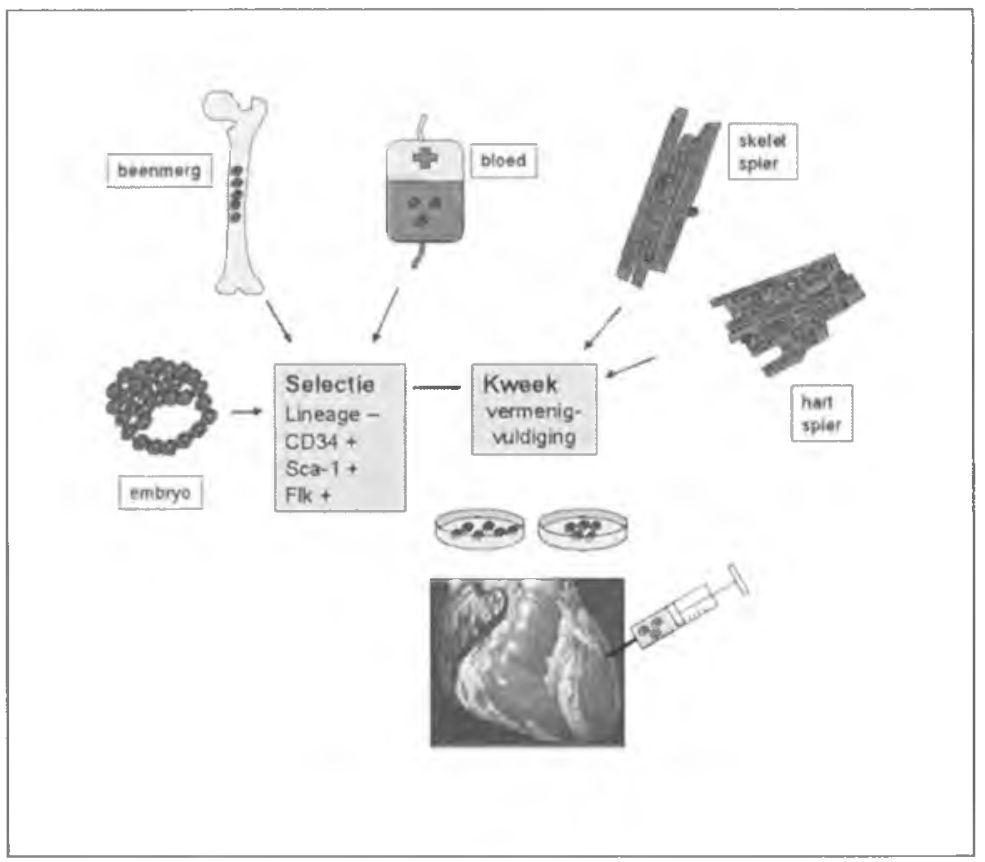

Figuur 7. Stamcellen kunnen uit beenmerg, bloed en weefsels gehaald worden. Door middel van selectie kan men een bijna pure stamcel populatie krijgen die vervolgens vermenigvuldigd moet worden. De stamcellen worden ingespoten, bijvoorbeeld in het hart. Een alternatief is om stamcellen uit embryo's te halen. Dit is omstreden en lijkt niet nodig te zijn. Uit Simons \& Post ${ }^{1}$

Wat is een stamcel? De ultieme stamcel is de bevruchte eicel waar we allemaal mee beginnen en die uiteindelijk leidt tot de veelheid van gespecialiseerde cellen waar ons lichaam uit bestaat. Een deel van de cellen specialiseren zich echter niet en blijven als ongedifferentieerde cellen in ons lichaam aanwezig, vooral in het beenmerg, maar in geringe mate ook in het bloed en onze organen (figuur 7). Zij zijn als het ware de koninginnen van het mierennest, ze kunnen zich eindeloos vermenigvuldigen en de kolonie van gespecialiseerde mieren vormen, de nestbouwers, de verkenners, de sjouwers, krijgers en voorraadkasten. Wie 
de koningin heeft, beheerst het mierennest, ofwel men hoeft maar een paar stamcellen te gebruiken om de hele arterie te bevolken.

De vraag is nu hoe we alle gewone mieren zover krijgen dat ze gespecialiseerde taken gaan uitvoeren? Hoe dit proces verloopt in een mierennest is grotendeels onbekend, maar het ligt voor de hand dat er selectie plaatsvindt. Men stuurt een verkenner op pad. Als deze verdwaalt of niet hard genoeg blijkt te kunnen lopen als er een miereneter in de buurt komt, is het een foute keus en wordt die automatisch afgestraft. Dit klinkt niet erg efficiënt en ik geloof dan ook niet dat er één bioloog is die de natuur efficient noemt. Ingenieurs proberen dit beter te doen. In het bloedvat moet de cel zich differentieren in drie celtypen, die elk een belangrijke functie van het bloedvat op zich nemen: endotheel, gladde spier en fibrocyt. Wat zijn de functies in de wand van de arterie? Ten eerste moet er bloed doorheen stromen dat niet onmiddellijk stolt wanneer het in aanraking komt met de wand. Hiervoor zorgt het endotheel. Omdat het bloed onder druk staat die bovendien gedurende elke hartslag fluctueert, moet de wand stevig en elastisch zijn, wat voornamelijk door fibrocyten en gladde spiercellen wordt verzorgd. Tenslotte moet de arteriewand ook nog snel kunnen reageren op veranderingen in bloedstroom. Tijdens inspanning stroomt er bijvoorbeeld tot 5 keer zoveel bloed door ons kransslagaderen dan wanneer we slapen, zonder dat de druk evenredig toeneemt. Dit kan alleen wanneer de diameter van onze arteriën mee verandert. Onze arterièn kunnen dus uitzetten en samentrekken, zoals onze spieren dat kunnen. Deze functies zijn dus voor een belangrijk deel mechanisch en specialisatie moet vooral leiden tot aanpassing van deze cellen aan mechanische omstandigheden. Het ligt dus voor de hand dat mechanische factoren invloed hebben op de differentiatie van cellen. In het laboratorium kunnen we stamcellen zeer nauwkeurig blootstellen aan mechanische prikkels en kunnen we hun differentiatie meten.

Als we in staat zijn om mechanische condities te vinden die de gewenste differentiatie van stamcellen in design arteriën bewerkstelligen, kunnen we wellicht de snelle replicatie van stamcellen combineren met een efficiente differentiatie en zo de arteriewand in korte tijd met alle noodzakelijke celtypes opbouwen. De eerste aanzet is hiertoe in Eindhoven inmiddels gedaan. Het blijkt dat bepaalde stamcellen, de zogenaamde mesenchymale stamcellen, kunnen differentieren tot endotheelcellen als ze blootgesteld worden aan een vloeistofstroom Als ze aan cyclische rek worden blootgesteld gaan ze kenmerken van gladde spiercellen vertonen. Deze verschillen zijn steeds gradueel en 
waarschijnlijk nog omkeerbaar. Enerzijds dient deze exercitie het snel en effectief kweken van bloedvaten en is dus op toepassing gericht. Anderzijds leren deze experimenten ons ook weer veel over de biologie van de arteriewand. Antwoorden op vragen als, "Welk differentiatie stadium van endotheel of gladde spier leidt tot productie van eiwitten"?, "Hoe veranderen de mechanische eigenschappen van deze cellen gedurende de differentiatie"? en "Hoe beinvloeden differentiërende cellen eikaars differentiatie"?, zullen ons inzicht belangrijk vergroten.

De omkeerbaarheid van differentiatie is een belangrijk wetenschappelijk probleem dat pas recent weer in de belangstelling is gekomen. Omdat het zeer moeilijk is om bijvoorbeeld hersencellen of hartcellen te kweken, werd verondersteld dat deze cellen zogenaamd terminaal gedifferentiëerd waren: ze konden alleen nog maar gespecialiseerd zijn en niet meer terugvallen naar een stamcel stadium of een andere specialisatie ondergaan. Dit concept is langzaam aan het veranderen. $\mathrm{Er}$ zijn verschillende overgangen beschreven van het ene naar het andere celtype. Als we controle krijgen over de condities die nodig zijn om de differentiatie van cellen te reprogrammeren zou dat onze Geneeskunde revolutionaliseren'4. Het wordt dan denkbaar dat we bijvoorbeeld bindweefselcellen in het litteken weefsel dat ontstaat na een hartinfarct kunnen transformeren in hartspier en zo de functie van het orgaan volledig herstellen. Voor bloedvaten lijkt dit probleem veel eenvoudiger. Endotheel cellen, gladde spiercellen en fibroblasten zijn gemakkelijk in kweek te houden en tot differentiatie, maar ook tot de-differentiatie aan te zetten. In feite is het lastig om endotheelcellen en gladde spiercellen in kweek in een gedifferentiëerde status te houden. Het is dus ook niet verwonderlijk dat tissue engineering van bloedvatweefsel verder gevorderd is dan van hartweefsel. Samenvattend kunnen we van het bouwen van een bloedvat enorm veel leren over de fundamentele biologie van de vaatwand en daarmee is voor mij ook een belangrijke rechtvaardiging gegeven om de samenwerking tussen Eindhoven en Maastricht op het gebied van vasculair onderzoek te verstevigen.

Naast het bouwen van 'design arteriën', is zoals gezegd de inbouw van een vaatnetwerk in een weefsel implantaat waarschijnlijk van groot belang voor de overleving van het implantaat. Ik heb met de voorbeelden over de vereiste farmacokinetiek van groeifactor toediening al aangegeven hoe ik denk dat dat aangepakt zou moeten worden. Omdat elk weefselimplantaat gevormd moet worden door o.a. het aanbrengen van gekweekte cellen, is het tamelijk eenvoudig om een minderheid van die cellen genetisch te modificeren om bijvoorbeeld VEGF te laten maken, 
gedurende langere of kortere tijd. Er zal een vaatnetwerk ontstaan dat hopelijk integreert met de bloedvaten van het orgaan waarin het weefsel geïmplanteerd wordt. Men wil niet de situatie van de Betuwelijn of de nieuwe Westerschelde tunnel nabootsen. Dat deze situatie niet hopeloos is, kunnen we leren uit de ontwikkeling van bijvoorbeeld de kransslagaderen in de foetale fase, waarbij deze eerst gevormd worden rond het hart en pas daarna aansluiting vinden bij de aorta van waaruit uiteindelijk de bloedtoevoer optreedt. Het is alsof twijgen van een boom groeien en daarna pas aansluiting zoeken bij de stam. Dit probleem is wellicht ook vergelijkbaar met dat van de relatie tussen angiogenetische vaatbedden en grotere collateraal arteriën.

\section{De toekomst van Fysiologie}

Het verhaal over stamcellen brengt me op de rol en de betekenis van de Fysiologie in de komende decennia zoals ik die zie omdat het mijns inziens een vraagstuk van differentiatie en dedifferentiatie is. Wat is Fysiologie en waarom hebben we deze discipline nodig?

Het is wellicht omineus dat ik deze vragen stel. Ze komen namelijk voort uit de constatering dat in Nederland, maar ook in het buitenland, vakgroepen Fysiologie uit sommige medische faculteiten zijn verdwenen, waarbij fysiologen zijn versnipperd over andere, meestal klinische, afdelingen. Dit is voor een groot deel te danken aan het verdwijnen van schotten tussen de diverse disciplines vooral in het onderzoek en dat zou ik willen duiden als een positieve ontwikkeling. Was vroeger het specialistisch onderzoek gericht op een discipline zoals Fysiologie, Farmacologie of Biochemie, tegenwoordig specialiseert men zich op een bepaald medisch of biologisch probleem, bijvoorbeeld atherosclerose of neovascularisatie, en beperkt dat vaak ook nog tot één orgaan-systeem. Deze specialisatie is onvermijdelijk en ook nodig met het oog op de explosief toenemende detail kennis.

Het onderwijs wordt mijns inziens nadelig getroffen door deze vergaande specialisatie. We moeten niet uit het oog verliezen dat studenten niet gebaat zijn bij diepgaande details, wanneer ze nog niet ingebed zijn in een inzichtelijk kader van samenhangende orgaanfuncties. Het is alsof men een gedetailleerd kaartje krijgt van het gebouw waarin men moet zijn, zonder een adres of routebeschrijving die aangeeft hoe daar te komen. We bevinden ons in Maastricht in de gunstige omstandigheid dat deze "oude" disciplines nog steeds bestaan. We krijgen van docenten en medici van universiteiten waar de Fysiologie is opgegaan in de diverse orgaan specialismen klachten over het niveau van kennis en begrip 
van orgaan functie in de samenhang van het hele menselijke lichaam. In het onderwijs is het nadelige effect van specialisatie zeer eenvoudig tegen te gaan door deze disciplines in stand te houden. in onze faculteit is de opleiding Geneeskunde aanzienlijk gewijzigd, waarbij het accent is komen te liggen op vroege kennismaking van studenten met daadwerkelijke patiënten en hun gezondheidsproblemen. Hierbij wordt het van het grootste belang geacht dat gedurende het gehele curriculum kennis en inzicht van de basisvakken als Fysiologie worden geïntegreerd in het klinische onderwijs. Hier is een zeer goed begin mee gemaakt, maar als Fysiologen hebben we de wens en de intentie om meer en diepgaander te participeren gedurende de klinische fasen van het Geneeskunde onderwijs. De Geneeskundestudie is een interessante mix van de internalisering van professionele kennis en vaardigheden en de ontwikkeling van medisch biologisch denken. Tijdens de klinische fasen van het onderwijs ligt de nadruk terecht op de eerste aspecten, maar het zou een ernstige degradering van het Geneeskunde onderwijs en meer nog van de uiteindelijke beroepsbeoefening zijn als dit niet steeds vergezeld gaat van begrip van het hoe en warom. Ofschoon we er nog weinig ervaring mee hebben ben ik er van overtuigd dat hetzelfde geldt voor de master opleiding in het biomedische onderzoek. Ook in het geven van onderwijs is het vermogen tot de-differentiatie even belangrijk als dat tot differentiatie en dit is mijns inziens beter gewaarborgd vanuit een afzonderlijke discipline Fysiologie die niet opgegaan is in orgaan specialismen. Dames en heren studenten, $u$ weet wellicht nog niet wat verdergevorderde collega's weten: Fysiologie wordt achteraf beschouwd als het vak dat het beste voorbereid op de latere klinische jaren en samen met Pathologie de belangrijkste voorbereiding vormt op co-schappen en klinische stages 15 . Wij zullen ons dus maximaal inzetten om u zo lang en intensief als mogelijk met Fysiologie-onderwijs lastig te vallen.

Voor het onderzoek geldt het belang van disciplines zoals gezegd in mindere mate. Onderzoek is zeer gespecialiseerd en zal zich meestal niet houden aan de grenzen van disciplines. Er is een mondiale trend om wetenschappelijk onderzoek te doen in grotere of kleinere samenwerkingsverbanden, waarbij elke participant zijn of haar specifieke expertise inbrengt. Het succes van het CARIM illustreert dit treffend. Deze trend loop parallel aan de eisen die we stellen aan het wetenschappelijk gehalte van onderzoek. Het is tegenwoordig voor goede tijdschriften niet voldoende meer om een bewijs via één aanpak te leveren. Als er andere methoden zijn die de bewijsvoering kunnen verifiëren of falsificeren, moeten deze ook worden gebruikt. Hierdoor 
wordt men gedwongen om veel methodieken te beheersen of ze op andere wijze toe te voegen aan het onderzoeksarsenaal, meestal door samenwerking met onderzoekers die specialist zijn in de ontbrekende methodiek. Omdat fysiologen erin gespecialiseerd zijn, worden de functie proeven meestal door ons gedaan, ongeacht of ze in reageerbuisjes, celkweken, geïsoleerde organen of hele organismen gedaan moeten worden. Nu het menselijk genoom bekend is en er een enorme taak ligt om de functies van al die genen in afzonderlijkheid en in samenhang te bestuderen, hoeven fysiologen voorlopig niet bang te zijn voor hun baan. Naarmate de functie van meer genen en eiwitten bekend worden, wordt het denkbaar dat we een meer geintegreerd beeld kunnen vormen van complexe regelsystemen in het lichaam. Naast kennis van deze functies zijn modellen nodig die de samenhang tussen de functies en regelsystemen beschrijven, gekoppeld aan een explosief toenemende rekencapaciteit. Dit geheel wordt wel beschreven als "systems biology", wat suggereert dat er "systems biologists" zijn. Deze bestaan niet en een team dat een medisch biologisch probleem in al zijn complexiteit wil omvatten zal een veelheid van disciplines, waaronder fysiologen, bevatten. Uit deze modellen gaan immers hypothesen komen die vervolgens functioneel getest moeten worden en hiervoor zijn functie specialisten, fysiologen dus, nodig.

Door de vervaging van discipline grenzen lijkt het voor het medisch biologisch onderzoek niet noodzakelijk om vast te houden aan groepen onderzoekers die per discipline georganiseerd zijn. Schadelijk is het echter ook niet. Daar waar het voor het onderzoek niet schadelijk is, is instandhouding van basis disciplines noodzakelijk voor handhaving van de kwaliteit en de integriteit van het onderwijs.

Tot slot wil ik nog vele mensen bedanken die mede de loop en intensiteit van mijn wetenschappelijke loopbaan bepaald hebben, waaronder de studenten, promovendi, collega's, supervisors en bestuurders. Een paar mensen wil ik hier uitlichten. Arjan Porsius heeft mij gedurende mijn peuterjaren als onderzoeker gevormd en geconditioneerd met gedragscodes, die ik nu als zeer nuttig omarm. Tot en met mijn wetenschappelijke puberteit heeft Cees Borst mijn eigengereidheid gecanaliseerd met zijn overweldigend en aanstekelijk enthousiasme. De adolescentie fase heb ik nog niet voltooid, but Mike Simons has contributed greatly to my energy and efficiency in academic research, while entertaining a wonderful friendship. Ik dank mijn huidige collega's van de Fysiologie en van CARIM voor hun hartelijke en professionele ont- 
vangst en beschouw het als een grote eer en blijk van vertrouwen dat ik de capgroep Fysiologie mag vertegenwoordigen in onze Universiteit. Een zelfde ontvangst heb ik genoten bij BMT in Eindhoven. Ik heb tot nog toe het geluk gehad dat ik heb mogen opgroeien in harmonieuze en constructieve onderzoeksgroepen en ben daar zeer dankbaar voor.

Hoewel ik besef dat ik de schijn tegen me heb, voel ik in toenemende mate dat mijn werk een stevig fundament heeft in mijn familie en vrienden kring en in het bijzonder Liesbeth, Lisanne en Bas. Zonder hen, zouden de talrijke ups en en nog talrijkere downs die inherent zijn aan het doen van wetenschappelijk onderzoek, op den duur ondraaglijk zijn.

Aan de wieg van mijn wetenschappelijke loopbaan heeft mijn vader gestaan, die op mijn mededeling dat ik Geneeskunde ging studeren, antwoordde met de woorden: "Dat is toch geen wetenschap!" Hem had $i k$ willen suggereren dat het toch nog een beetje is goed gekomen.

Ik heb gezegd 
1. Simons M, Post MJ. Angiogenesis. In: Topol EJ, ed. Textbook of Interventional Cardiology. 4th ed. Philadelphia: Saunders; 2003:757-779.

2. Folkman J. Angiogenesis and apoptosis. Semin Cancer Biol. 2003;13:159-167.

3. Grikscheit TC, Vacanti JP. The history and current status of tissue engineering: The future of pediatric surgery. J Pediatr Surg. 2002;37:277-288.

4. Cao Y, Hong A, Schulten H, Post MJ. Update on therapeutic neovascularization. Cardiovasc Res. 2005;65:639-648.

5. Zhu $H$, Bunn HF. Signal transduction. How do cells sense oxygen? Science. 2001;292:449-451.

6. Simons $M$. Therapeutic coronary angiogenesis: a fronte praecipitium a tergo lupi? Am J Physiol Heart Circ Physiol. 2001;280:H1923-1927.

7. Simons $M$, Bonow RO, Chronos NA, Cohen DJ, Giordano FJ, Hammond HK, Laham RJ, Li W. Pike $M$. Sellke FW. Stegmann TJ, Udelson JE, Rosengart TK. Clinical trials in coronary angiogenesis: issues, problems, consensus: An expert panel summary. Circulation. 2000;102:E73-86

8. Dor Y. Djonov V. Abramovitch R, Itin A, Fishman Gl, Carmeliet P, Goelman C, Keshet $E$. Conditional switching of VEGF provides new insights into adult neovascularization and pro-angiogenic therapy. Embo J. 2002;21:1939-1947.

9. Cao R, Brakenhielm E, Pawliuk R, Wariaro D, Post MJ, Wahlberg E, Leboulch P, Cao Y. Angiogenic synergism, vascular stability and improvement of hind-limb ischemia by a combination of PDGF-BB and FGF-2. Nat Med. 2003;9:604-613.

10. Ozawa CR, Banfi A, Glazer NL, Thurston G, Springer ML, Kraft PE, McDonald DM, Blau HM. Microenvironmental VEGF concentration, not total dose, determines a threshold between normal and aberrant angiogenesis. J Clin Invest. 2004;113:516-527.

11. Epstein SE, Kornowski R, Fuchs S, Dvorak HF. Angiogenesis therapy: amidst the hype, the neglected potential for serious side effects. Circulation. 2001;104:115119.

12. Friedmann T. Overcoming the obstacles to gene therapy. Sci Am. 1997;276:96101.

13. Helisch A, Schaper W. Arteriogenesis: the development and growth of collateral arteries. Microcirculation. 2003:10:83-97.

14. Mironov V, Visconti RP, Markwald RR. What is regenerative medicine? Emergence of applied stem cell and developmental biology. Expert Opin Biol Ther. 2004:4:773-781.

15. Frank $M$, Matyas $M$. The Status of Physiologists and Physiology at US Medical Schools. The Physiologist. 2002;45:179-180. 
